\title{
Novel fish hypothalamic neuropeptides stimulate the release of gonadotrophins and growth hormone from the pituitary of sockeye salmon
}

\author{
Masafumi Amano, Shunsuke Moriyama, Masayuki ligo ${ }^{1}$, \\ Shoji Kitamura ${ }^{2}$, Noriko Amiya, Kunio Yamamori, \\ Kazuyoshi Ukena ${ }^{3}$ and Kazuyoshi Tsutsui ${ }^{3}$ \\ School of Fisheries Sciences, Kitasato University, Ofunato, Iwate 022-0101, Japan \\ ${ }^{1}$ Department of Applied Biochemistry, Faculty of Agriculture, Utsunomiya University, Utsunomiya, Tochigi 321-8505, Japan \\ ${ }^{2}$ Freshwater Fisheries Research Division, National Research Institute of Fisheries Science, Nikko, Tochigi 321-1661, Japan \\ ${ }^{3}$ Laboratory of Brain Science, Faculty of Integrated Arts and Sciences, Hiroshima University, Higashi-Hiroshima 739-8521, Japan \\ (Requests for offprints should be addressed to K Tsutsui; Email: tsutsui@hiroshima-u.ac.jp)
}

\begin{abstract}
We recently identified a cDNA encoding three novel fish hypothalamic neuropeptides, having LPXRF-NH $\mathrm{N}_{2}$ from the goldfish brain. In this study, to clarify the physiological functions of these three LPXRFamide peptides (gfLPXRFa-1, -2, and -3), we analysed the localisation and hypophysiotrophic activity of these peptides using sockeye salmon, Oncorhynchus nerka, in which immunoassay systems for several anterior pituitary hormones have been developed. gfLPXRFa-immunoreactive cell bodies were detected in the nucleus posterioris periventricularis of the hypothalamus and immunoreactive fibres were distributed in various brain regions and the pituitary.
\end{abstract}

We also detected gfLPXRFa-immunoreactivity in the pituitary by competitive enzyme-linked immunosorbent assay combined with reversed-phase HPLC. These three gfLPXRFamide peptides stimulated the release of FSH, $\mathrm{LH}$ and $\mathrm{GH}$, but did not affect the release of prolactin (PRL) and somatolactin (SL) from cultured pituitary cells. These results suggest that novel fish hypothalamic LPXRFamide peptides exist in the brain and pituitary of sockeye salmon and stimulate the release of gonadotrophins and $\mathrm{GH}$ from the pituitary.

Journal of Endocrinology (2006) 188, 417-423

\section{Introduction}

Neuropeptides containing a C-terminal -Arg-Phe- $\mathrm{NH}_{2}$ sequence (RFamide peptides) have been identified in the brains of several vertebrates. RFamide peptides have been shown to have important physiological roles in neuroendocrine, behavioural, sensory and autonomic functions (Panula et al. 1996, 1999, Ibata et al. 2000).

We previously identified a novel hypothalamic dodecapeptide, Ser-Ile-Lys-Pro-Ser-Ala-Tyr-Leu-Pro-Leu-ArgPhe- $\mathrm{NH}_{2}$, in the brain of Japanese quail Coturnix japonica (Tsutsui et al. 2000). This dodecapeptide was shown to be located in the hypothalamo-hypophysial system and to inhibit gonadotrophin (GTH) release, it was therefore dubbed gonadotrophin-inhibiting hormone $(\mathrm{GnIH}$; Tsutsui et al. 2000). GnIH-immunoreactive (ir) cell bodies and terminals were localized in the paraventricular nucleus and median eminence, respectively, indicating that GnIH acts directly on the pituitary (Tsutsui et al. 2000, Ubuka et al. 2003, Ukena et al. 2003a). GnIH-ir fibres were further observed in extremely close proximity to gonadotrophin-releasing hormone (GnRH) neurons in the preoptic area in birds (Bentley et al. 2003, Ukena et al. $2003 a$ ). It is therefore suggested that $\mathrm{GnIH}$ acts at the level of the hypothalamus to regulate GTH release, as well as at the pituitary. We also characterized a cDNA encoding the GnIH precursor in the brain of Japanese quail (Satake et al. 2001) and Gambel's white-crowned sparrow Zonotrichia leucophrys gambelii (Osugi et al. 2004). The GnIH precursor encodes one GnIH and two GnIH-related peptides (GnIH-RP-1 and GnIH-RP-2) that include Leu-ProXaa-Arg-Phe- $\mathrm{NH}_{2}(\mathrm{Xaa}=\mathrm{Leu}$ or Gln) at their C-termini (Satake et al. 2001, Osugi et al. 2004). Based on this structural feature, GnIH and GnIH-RPs are considered to be LPXRFamide peptides (where $\mathrm{X}=\mathrm{L}$ or $\mathrm{Q}$ ) as a new member of the RFamide peptide family (see Ukena and Tsutsui 2005).

We further identified LPLRFamide peptide from the bullfrog hypothalamus which possessed growth hormone (GH) releasing activity, and was designated as frog GHreleasing peptide (fGRP) (Koda et al. 2002). The fGRP precursor also encodes one fGRP and three related peptides 
(fGRP-RP-1, -2, and -3; Sawada et al. 2002a), which were identified as mature LPXRFamide peptides (Ukena et al. 2003b). Among them, fGRP-RP-2 stimulated not only $\mathrm{GH}$, but also prolactin (PRL) release (Ukena et al. 2003b).

cDNAs that encode novel RFamide peptides similar to GnIH and fGRP have been detected in mammalian brains with a gene database search (Hinuma et al. 2000). The cDNAs of human and bovine peptides encode three peptides, which were dubbed RFamide-related peptide-1, -2 , and -3 (RFRP-1, -2 , and -3 ). RFRP-1 and -3 are both mammalian LPXRFamide peptides. Intracerebroventricular administration of the deduced human LPXRFamide peptide, hRFRP-1, increased PRL release in the rat (Hinuma et al. 2000). Thus, to establish that LPXRFamide peptides generally contribute to the regulation of pituitary hormone release in vertebrates, we need to identify fish LPXRFamide peptides and clarify their hypophysiotrophic activities in fish.

Recently, a cDNA that encoded three novel fish LPXRFamide peptides (gfLPXRFa-1, -2, and -3) was characterised from the goldfish Carassius auratus brain, and gfLPXRFa-3 was identified as a mature peptide (Sawada et al. 2002b). Distribution of gfLPXRFamide peptides in the brain of goldfish was further examined by immunohistochemistry. Immunoreactive cell bodies were restricted to the nucleus posterioris periventricularis $(\mathrm{NPPv})$ and the nervous terminalis (NT), and immunoreactive fibres were distributed in several brain regions, including the nucleus lateralis tuberis pars posterioris (NLTp) and pituitary (Sawada et al. 2002b). In light of previous reports in other vertebrates (Tsutsui et al. 2000, Hinuma et al. 2000, Koda et al. 2002, Ukena et al. 2003b, Osugi et al. 2004), and considering that gfLPXRFamide peptides innervated the pituitary of the goldfish, it is hypothesized that gfLPXRFamide peptides act on the pituitary to regulate pituitary hormone secretion.

Therefore, in this study, we examined whether gfLPXRFamide peptides, newly identified fish hypothalamic LPXRFamide peptides, have releasing activities on anterior pituitary hormones, i.e. follicle-stimulating hormone (FSH), luteinizing hormone (LH), GH, PRL and somatolactin (SL), using cell cultures of sockeye salmon Oncorhynchus nerka pituitaries, in which immunoassays for all these hormones have been developed. Prior to the culture study, we confirmed that gfLPXRFa-like substances are present in the brain and pituitary of sockeye salmon by immunohistochemistry and competitive ELISA combined with reversed-phase HPLC.

\section{Materials and Methods}

Animals

Sockeye salmon reared in well water of constant temperature $\left(9-10{ }^{\circ} \mathrm{C}\right)$ at the Freshwater Fisheries Research Division,
National Research Institute of Fisheries Science (Nikko, Tochigi Prefecture, Japan) were used. The experimental protocol was approved in accordance with the Guide for the Care and Use of Laboratory Animals prepared by the Kitasato University, Utsunomiya University and the National Research Institute of Fisheries Science, Japan.

\section{Immunohistochemistry}

We used 13 fish for immunohistochemistry. Fish were anaesthetised by immersion in 0.05\% 2-phenoxyethanol. Immunohistochemistry was conducted using paraplast sections. Brains were fixed with Bouin's fluid for $48 \mathrm{~h}$ at $4{ }^{\circ} \mathrm{C}$ and subsequently rinsed in cold $70 \%$ ethanol, dehydrated through a graded series of ethanol concentrations and embedded in paraplast. Serial sagittal or frontal sections were cut at 5 or $8 \mu \mathrm{m}$, separated into four groups every two sections, and mounted on gelatinized slides. The antibody against fGRP was diluted 1000-fold with $0 \cdot 1 \mathrm{M}$ phosphate buffer $(\mathrm{pH} 7 \cdot 4)$ raised in Tsutsui's laboratory (Koda et al. 2002), and contained $0 \cdot 75 \% \mathrm{NaCl}$ and $0 \cdot 3 \%$ Triton $\mathrm{X}-100$. The specificity of the antibody was checked by a competitive ELISA in a previous study (Sawada et al. 2002b). The $I C_{50}$ values (concentrations yielding $50 \%$ displacement) in the competitive ELISA were estimated as follows; $0.46 \mathrm{pmol}$ for gfLPXRFa-1, 3.43 pmol for gfLPXRFa-2, 1.13 pmol for gfLPXRFa-3, 0.74 pmol for fGRP, 20.96 pmol for chicken RFamide (LPLRFamide) and more than $1000 \mathrm{pmol}$ for other RFamide peptides, e.g., Carassius RFamide (SPEIDPFW YVGRGVRPIGRFamide) and molluscan RFamide (FMRFamide). For immunohistochemical reactions, a Histofine immunostaining kit (Nichirei, Tokyo, Japan) was used for all immunohistochemical reactions detailed. To test the specificity of immunoreactions, the antiserum was pre-adsorbed overnight at $4{ }^{\circ} \mathrm{C}$ with an excess amount of gfLPXRFa-1, -2 or -3 (50 $\mu \mathrm{g}$ gfLPXRFa/ml). The subsequent procedure was as described above.

\section{Reversed-phase HPLC}

Pituitary glands from 140 precocious males (approximately $250 \mathrm{~g}$ body weight) were boiled for $7 \mathrm{~min}$ and homogenised in 5\% acetic acid as described previously (Tsutsui et al. 2000, Sawada et al. 2002b). The homogenate was centrifuged at $15000 \mathrm{~g}$ for $20 \mathrm{~min}$ at $4{ }^{\circ} \mathrm{C}$ and the supernatant was collected. The supernatant was passed through a disposable C-18 cartridge column (Sep-pak; Waters, Milford, MA, USA) and the retained material, eluted with $60 \%$ methanol, was loaded onto a reversedphase HPLC column (ODS-80TM; Tosoh, Tokyo, Japan) with a linear gradient of $15-31 \%$ acetonitrile $\left(\mathrm{CH}_{3} \mathrm{CN}\right)$ containing $0.1 \%$ trifluoroacetic acid for $40 \mathrm{~min}$ at a flow rate of $0.5 \mathrm{ml} / \mathrm{min}$. The fractions $(1 \mathrm{ml}$ each/tube) were then subjected to a competitive ELISA using the antibody raised against fGRP. 


\section{Pituitary cell culture}

100 precocious males (approximately $100 \mathrm{~g}$ body weight) were anaesthetised in $0.05 \%$ 2-phenoxyethanol and decapitated. Pituitaries were immediately dissected out, kept in ice-cold Minimum Essential Medium (MEM; Gibco, Grand Island, NY, USA) containing 0.1\% bovine serum albumin (BSA; Sigma, St Louis, MO, USA) and $0 \cdot 01 \%$ antibiotic-antimycotic solution (Gibco), and immediately transported to Utsunomiya University (Utsunomiya, Tochigi Prefecture, Japan) where the dissociation procedure was carried out. Pituitaries were washed with Hank's balanced salt solution without $\mathrm{Ca}^{2+}$ and $\mathrm{Mg}^{2+}$ (HBSS), minced with a tissue slicer (Narishige, Tokyo, Japan), and treated with $0 \cdot 2 \%$ collagenase type $\mathrm{V}$ (Sigma) and 0.005\% DNase (Deoxyribonuclease Grade II; Boehringer Mannheim Biochemicals, Indianapolis, IN, USA) in HBSS in a spinner flask (Wheaton Science Products, Millville, NJ, USA) at 80 r.p.m. for $60 \mathrm{~min}$ at $18{ }^{\circ} \mathrm{C}$. Partially digested tissues were separated by centrifugation at $80 \mathrm{~g}$ for $5 \mathrm{~min}$ at $18^{\circ} \mathrm{C}$, and pituitary cells were dispersed by pipetting in the culture medium (see below). The viability of the cells tested with a trypan-blue exclusion test was $>90 \%$. Cells were plated on poly-Llysine-coated 24-well dishes (Iwaki, Tokyo, Japan) at a density of $5 \times 10^{4}$ cells/well in $1 \mathrm{ml}$ MEM containing $25 \mathrm{mM}$ Hepes (Dojin, Kumamoto, Japan), $1.4 \mathrm{mM}$ L-glutamine (Gibco), 10\% fetal bovine serum (ICN Biomedicals, Aurora, OH, USA), and 0.01\% antibioticantimycotic solution and preincubated at $18{ }^{\circ} \mathrm{C}$ for $72 \mathrm{~h}$ under a humidified atmosphere in 100\% air. Cells were plated into 52 wells: seven wells for the control group and the remaining 45 wells for the gfLPXRFamide peptide treatment groups (nine treatment groups of three peptides at three concentrations in five wells each). To examine the effects of gfLPXRFamide peptides on pituitary hormone release, cells were washed twice with $1 \mathrm{ml}$ MEM containing $0 \cdot 1 \%$ BSA and $0 \cdot 01 \%$ antibiotic-antimycotic solution and then incubated with or without gfLPXRFa-1, -2 , or $-3\left(10^{-9}, 10^{-7}\right.$, or $\left.10^{-5} \mathrm{M}\right)$ in the same medium for an additional $2 \mathrm{~h}$ at $18{ }^{\circ} \mathrm{C}$. Culture media were collected at the end of incubation and immediately frozen and kept at $-80{ }^{\circ} \mathrm{C}$ until amounts of pituitary hormones released could be determined by time-resolved fluoroimmunoassay (TR-FIA) or RIA.

\section{Immunoassays}

Released GTH levels were measured by TR-FIA for salmonid FSH and LH (Amano et al. 2000). Released GH, PRL and SL levels were measured by RIAs (Swanson 1995).

\section{Statistics}

Results of immunoassays were expressed as the mean \pm S.E. The effects of gfLPXRFa-1, -2 and -3 on the release of
FSH, LH, GH, PRL and SL from cultured pituitary cells were analysed for significance by one-way ANOVA followed by Dunnett's test.

\section{Results}

Distribution of novel fish LPXRFamide peptides in the brain and pituitary

We first investigated the localisation of the novel fish LPXRFamide peptides in the sockeye salmon brain and pituitary by immunohistochemistry. Pre-adsorption of the antibody with synthetic gfLPXRFa-1, -2 , or -3 resulted in the disappearance of the reaction product in the brain (Fig. 1B, C, D) and the neurohypophysis of the pituitary (Fig. 1H for gfLPXRFa-3, data not shown for gfLPXRFa-1 and -2), indicating that the antibody recognises these three peptides. The distribution of gfLPXRFa-ir cell bodies and fibres is summarized in Figure 2. Immunoreactive cell bodies were localized in the NPPv of the hypothalamus (Fig. 1A, E). Immunoreactive fibres were distributed in various brain regions from the olfactory bulb (OB) to the spinal cord, except for the cerebellum. In addition, some immunoreactive fibres projected to the pituitary (Fig. 1F, G).

Detection of novel fish LPXRFamide peptides in the pituitary by reversed-phase HPLC and ELISA

To detect gfLPXRFa-immunoreactivity in the pituitary gland, we carried out the competitive ELISA in conjunction with reversed-phase HPLC. Three gfLPXRFaimmunoreactive peaks were detected in fractions around 12, 16 and 18, exhibiting similar retention times to gfLPXRFa-2, -3 and -1 , respectively (Fig. 3). The immunoreactive peak corresponding to gfLPXRFa-3 seemed to be much smaller than the other two peaks.

Effects of novel fish LPXRFamide peptides on the release of FSH, LH, GH, PRL and SL from pituitary cells

Using primary cultures of sockeye salmon pituitaries, we then conducted experiments to ascertain whether gfLPXRFamide peptides have any influence on the release of anterior pituitary hormones such as FSH, LH, GH, PRL and SL. As shown in Figure 4A, gfLPXRFa-1, -2 and -3 significantly stimulated FSH release. The stimulatory effect of these peptides tended to be dose-dependent. The threshold concentrations of gfLPXRFa-1, -2 and -3 ranged less than $10^{-9} \mathrm{M}$, between $10^{-9}$ and $10^{-7} \mathrm{M}$, and between $10^{-9}$ and $10^{-7} \mathrm{M}$, respectively (Fig. 4A). Similarly, these three peptides significantly stimulated LH release (Fig. 4B). The stimulatory effect also tended to be dose-dependent and the threshold concentrations of gfLPXRFa-1, -2 and -3 ranged between $10^{-9}$ and $10^{-7} \mathrm{M}$, 

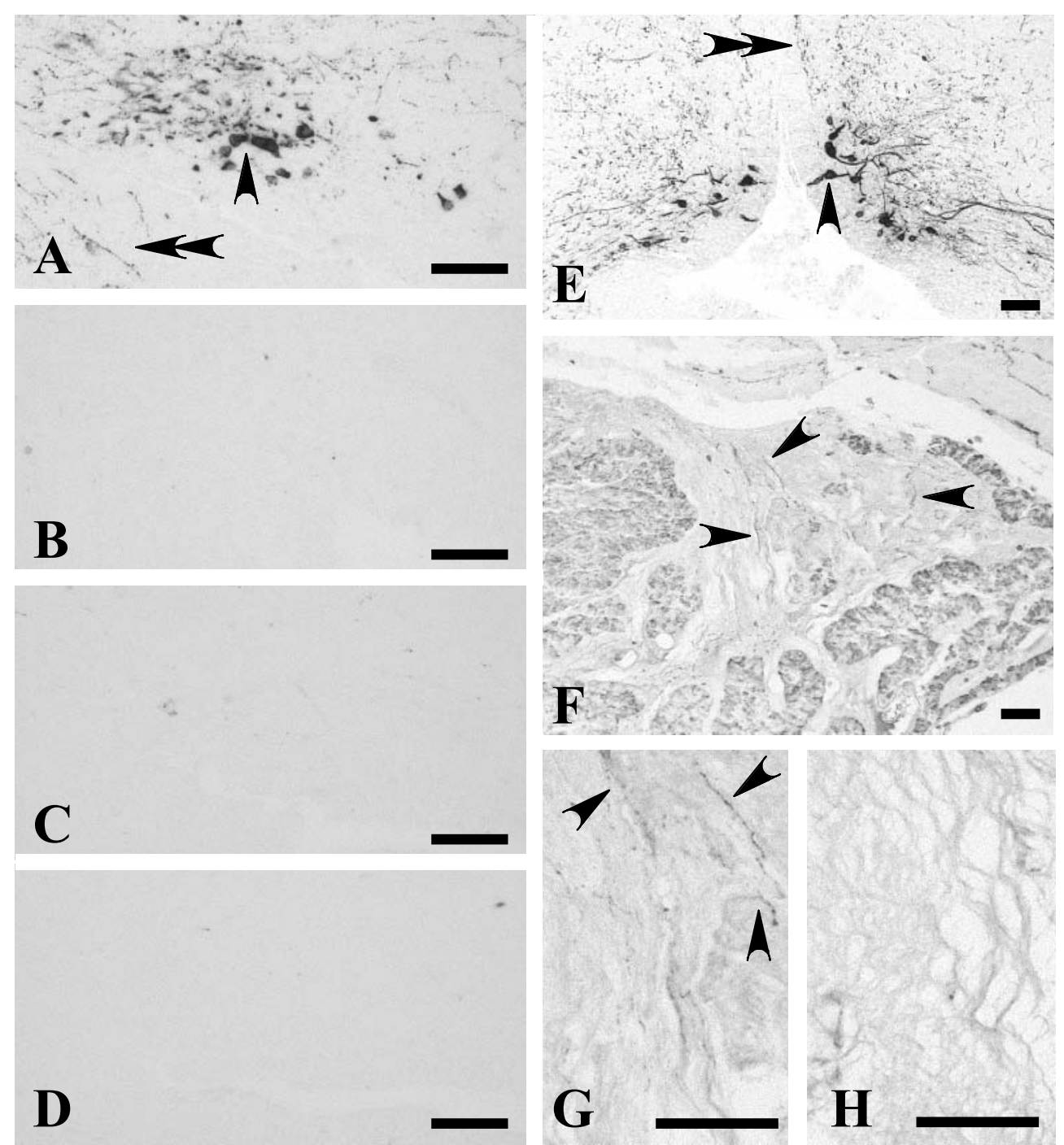

Figure 1 (A) Sagittal section through the hypothalamus of sockeye salmon. Arrowhead and double arrowhead indicate gfLPXRFa-ir cell bodies and fibres, respectively. (B) Adjacent section of (A) that was incubated with pre-adsorption antibody with the synthetic gfLPXRFa-1. (C) Adjacent section of (A) that was incubated with pre-adsorption antibody with the synthetic gfLPXRFa-2. (D) Adjacent section of (A) that was incubated with pre-adsorption antibody with the synthetic gfLPXRFa-3. (E) Frontal section through the hypothalamus. Arrowhead and double arrowhead indicate gfLPXRFa-ir cell bodies and fibres, respectively. (F) Sagittal section through the pituitary. Arrowheads indicate gfLPXRFa-ir fibres. (G) Sagittal section through the pituitary (higher magnification of $(F)$ ). Arrowheads indicate gfLPXRFa-ir fibres. (H) Adjacent section of (G) that was incubated with pre-adsorption antibody with the synthetic gfLPXRFa-3. Bars indicate $50 \mu \mathrm{m}$.

between $10^{-9}$ and $10^{-7} \mathrm{M}$, and less than $10^{-9} \mathrm{M}$, respectively (Fig. 4B). In addition to FSH and $\mathrm{LH}$, gfLPXRFa-1, -2 and -3 significantly stimulated GH release in a dose-dependent manner. The threshold concentrations of gfLPXRFa-1, -2 and -3 ranged from $10^{-9}$ and $10^{-7} \mathrm{M}, 10^{-7}$ and $10^{-5} \mathrm{M}$, and $10^{-9}$ and $10^{-7} \mathrm{M}$, respectively (Fig. 4C). On the other hand, none of the three gfLPXRFamide peptides had a significant effect on the release of PRL (Fig. 4D) and SL (Fig. 4E).

\section{Discussion}

Pre-adsorption of the antibody with the synthetic gfLPXRFa-1, -2 , or -3 resulted in disappearance of the reaction product in the brain and the neurohypophysis of the pituitary in the sockeye salmon, indicating that the antibody recognises these three peptides. gfLPXRFa-ir cell bodies were localised in the NPPv of the hypothalamus. Unlike goldfish (Sawada et al. 2002b), 


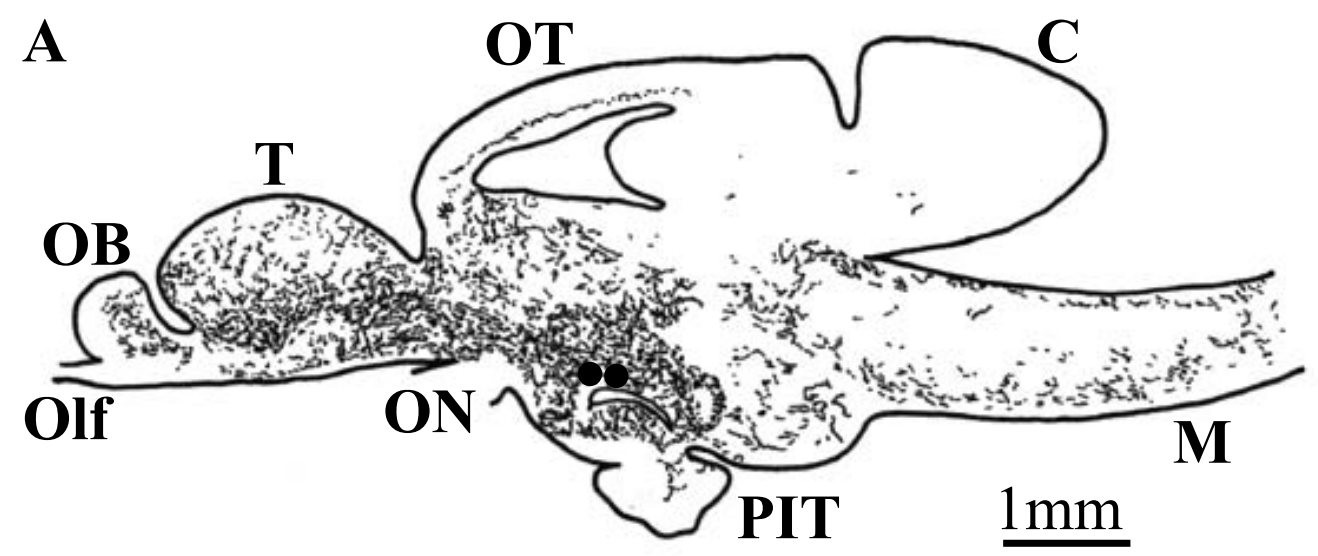

B

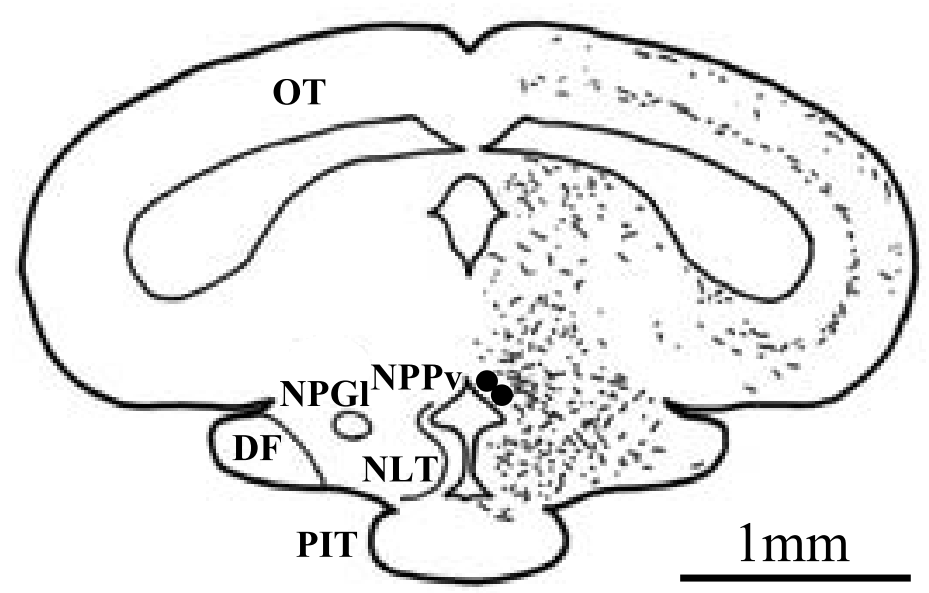

Figure 2 Schematic illustration of the distribution of gfLPXRFa-ir cell bodies (large dots) and gfLPXRFa-ir fibres in a parasagittal section $(A)$ and a frontal section (B) of sockeye salmon brain. Bars indicate $1 \mathrm{~mm}$. C, cerebellum; DF, nucleus diffuses of the inferior lobe; $M$, medulla oblongata; NLT, nucleus lateralis tuberis; NPGl, nucleus preglomerulosus lateralis; NPPv, nucleus posterioris periventricularis; OB, olfactory bulb; Olf, olfactory nerve; ON, optic nerve; OT, optic tectum; PIT, pituitary; T, telencephalon.

immunoreactive cell bodies were not detected in the NT of the sockeye salmon. In sockeye salmon, immunoreactive fibres are distributed in various brain regions from the $\mathrm{OB}$ to the spinal cord, except for the cerebellum. Interestingly, some immunoreactive fibres further projected to the pituitary gland. In addition, we could detect gfLPXRFa-immunoreactivity in the pituitary by the competitive ELISA combined with reversed-phase HPLC. This analysis suggested that plural LPXRFamide peptide-like substances are present in the pituitary of sockeye salmon, as immunoreactive peaks corresponding to gfLPXRFa-1, -2 and -3 were detected. This is supported by the fact that the three peptides, gfLPXRFa-1, -2 and -3 , were encoded in identical precursor cDNA (Sawada et al. 2002b). These immunochemical results suggest that novel fish LPXRFamide peptide-like substances act directly on the pituitary to regulate pituitary hormone secretion. Thus, we examined whether these three peptides regulate pituitary hormone release in vitro.

All three fish LPXRFamide peptides, gfLPXRFa-1, -2 and -3 , stimulated the release of FSH and $\mathrm{LH}$ from cultured pituitary cells of sockeye salmon, and these effects on GTHs may be dose-dependent. Moreover, gfLPXRFa-1, -2 and -3 also stimulated GH release in a dose-dependent manner. On the other hand, gfLPXRFa-1, -2 and -3 did not affect the release of PRL and SL. The stimulatory effects of these three peptides on the release of GTHs and GH may be taken as physiological actions, because threshold concentrations ranged from less than $10^{-5} \mathrm{M}(\mathrm{GH}), 10^{-7} \mathrm{M}$ (FSH) to $10^{-9} \mathrm{M}$ (LH). 


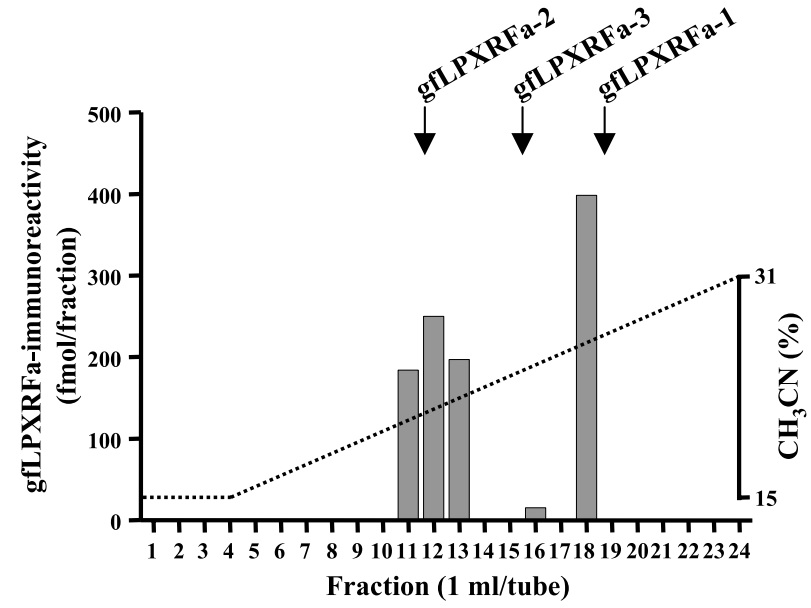

Figure 3 Reversed-phase HPLC profile of gfLPXRFa-immunoreactivity in the pituitary. The retained material was loaded onto a reversed-phase HPLC column with a linear gradient of 15-31\% acetonitrile $\left(\mathrm{CH}_{3} \mathrm{CN}\right)$ containing $0 \cdot 1 \%$ trifluoroacetic acid for $40 \mathrm{~min}$ at a flow rate of $0.5 \mathrm{ml} / \mathrm{min}$. gfLPXRFa-immunoreactivities in the fractions obtained from HPLC were evaluated by the competitive ELISA and are shown by solid columns. Arrows indicate the retention times of synthetic gfLPXRFa-1, -2 and -3 .

Thus, gfLPXRFamide peptides may be a novel factor regulating pituitary hormone secretion in fish. It has been reported that fGRP-RP-2 stimulates not only GH, but also PRL release both in vitro and in vivo in the bullfrog (Ukena et al. 2003b). Therefore, it is considered that LPXRFamide peptides regulate the release of plural pituitary hormones in frogs as well as fish.

Considering that GnIH, an avian LPXRFamide peptide, inhibits the release of GTHs (Tsutsui et al. 2000, Osugi et al. 2004), and fGRP and fGRP-RP-2, frog LPXRFamide peptides, stimulate the release of GH and GH/PRL, respectively (Ukena et al. 2003b), it is likely that gfLPXRFa-1, -2 and -3, fish LPXRFamide peptides, are also involved in the regulation of pituitary hormone secretion. The present study indicates that gfLPXRFa-1, -2 and -3 stimulate the release of GTHs and GH, suggesting that these fish LPXRFamide peptides function like GnRH and GH-releasing hormone $(\mathrm{GHRH})$. In sockeye salmon, salmon GnRH (sGnRH), which is distributed from the olfactory nerve through the hypothalamus, is involved in the release of GTH (Amano et al. 1998). Furthermore, salmon GHRH (sGHRH) was identified in sockeye salmon (Parker et al. 1993) and a stimulatory effect of sGHRH on GH release from the pituitary of coho salmon Oncorhynchus kisutch was reported (Parker et al. 1997). There is no report indicating physiological changes in plasma FSH, LH and GH levels in sockeye salmon. To understand the physiological roles of gfLPXRFamide peptides in fish reproduction and growth, we need to examine physiological changes in circulating $\mathrm{FSH}, \mathrm{LH}$ and $\mathrm{GH}$ levels and the effects of

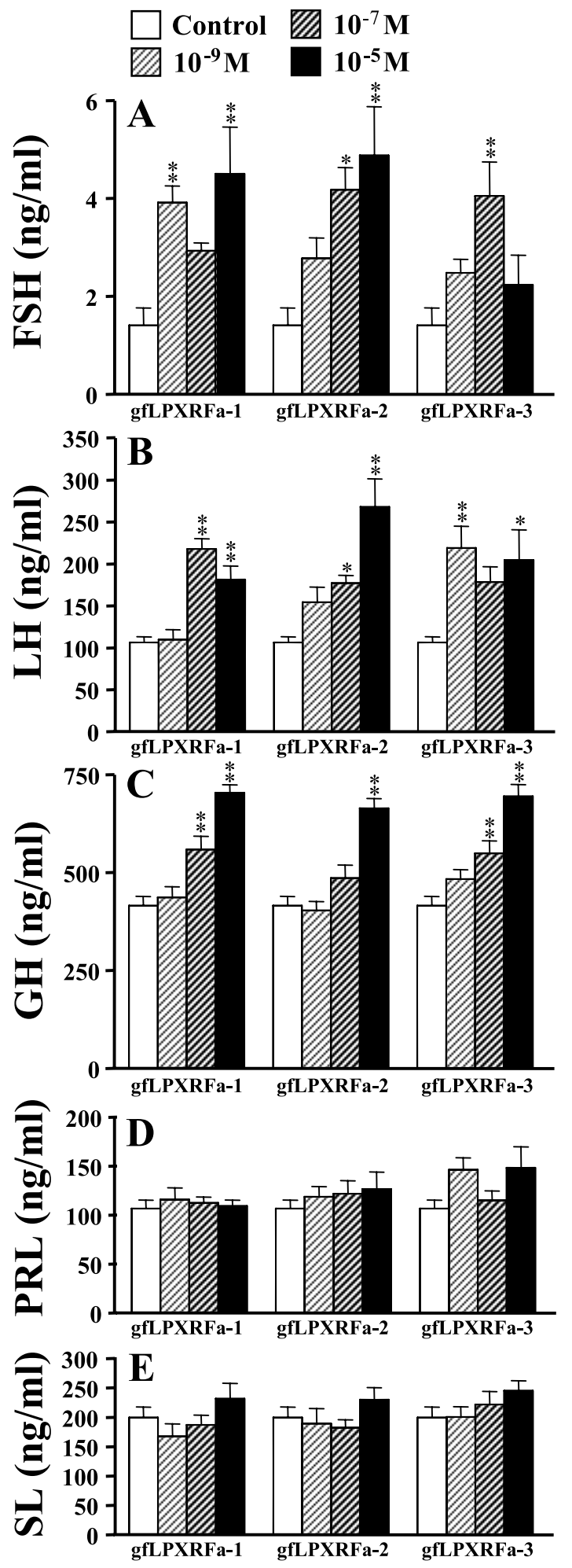

Figure 4 Changes in released levels of (A) $\mathrm{FSH},(B) \mathrm{LH},(\mathrm{C}) \mathrm{GH}$, (D) PRL and (E) SL. Each column and vertical line represents the mean \pm S.E. of determinations $(n=5-7)$. ${ }^{*} P<0 \cdot 05$; ${ }^{* *} P<0 \cdot 01$ (vs. control group). 
in vivo administration of gfLPXRFamide peptides on these hormone levels in sockeye salmon. Moreover, it will be interesting to examine the relationship between sGnRH, GHRH and gfLPXRFamide peptides in the future.

In conclusion, we have shown that gfLPXRFa-1, -2 and -3 stimulate the release of GTHs and GH from the pituitary, but do not stimulate the release of PRL and SL. These findings strengthen the view that LPXRFamide peptides, a new member of the hypothalamic RFamide peptide family, contribute to the multifactorial regulation of pituitary hormone release in vertebrates from fish to mammals. Moreover, judging from the wide distribution of immunoreactive fibres in the brain of sockeye salmon, it is suggested that gfLPXRFamide peptides function as neuromodulators and/or neurotransmitters in the brain. Further study is needed to clarify these functions of novel fish LPXRFamide peptides.

\section{Acknowledgements}

This work was supported in part by Grants-in-Aid for Scientific Research from the Ministry of Education, Science and Culture, Japan (13210101, 15207007 and 16086206 to KT; 15770040 to KU). The authors declare that there is no conflict of interest that would prejudice the impartiality of this scientific work.

\section{References}

Amano M, Ashihara M, Yoshiura Y, Kitamura S, Ikuta K \& Aida K 1998 Two differing salmon GnRH precursor mRNAs are co-expressed in the brain of sockeye salmon (Oncorhynchus nerka). Cell and Tissue Research 292 267-273.

Amano M, Iigo M, Ikuta K, Kitamura S, Yamada H, \& Yamamori K 2000 Roles of melatonin in gonadal maturation of underyearling precocious male masu salmon. General and Comparative Endocrinology 120 190-197.

Bentley GE, Perfito N, Ukena K, Tsutsui K \& Wingfield JC 2003 Gonadotrophin-inhibitory peptides in song sparrow (Melospiza melodia) in different reproductive conditions, and in house sparrows (Passer domesticus) relative to chicken-gonadotrophin-releasing hormone. Journal of Neuroendocrinology 15 794-802.

Hinuma S, Shintani Y, Fukusumi S, Iijima N, Matsumoto Y, Hosoya M, Fujii R, Watanabe T, Kikuchi K, Terao Y et al. 2000 New neuropeptides containing carboxy-terminal RFamide and their receptor in mammals. Nature Cell Biology 2 703-708.

Ibata Y, Iijima N, Kataoka Y, Kakihara K, Tanaka M, Hosoya M \& Hinuma S 2000 Morphological survey of prolactin-releasing peptide and its receptor with special reference to their functional roles in the brain. Neuroscience Research 38 223-230.

Koda A, Ukena K, Teranishi H, Ohta S, Yamamoto K, Kikuyama S \& Tsutsui K 2002 A novel amphibian hypothalamic neuropeptide: isolation, localisation and biological activity. Endocrinology 143 411-419.
Osugi T, Ukena K, Bentley GE, O’Brien S, Moore IT, Wingfield JC \& Tsutsui K 2004 Gonadotrophin-inhibitory hormone in Gambel's white-crowned sparrow (Zonotrichia leucophrys gambelii): cDNA identification, transcript localisation and functional effects in laboratory and field experiments. Journal of Endocrinology 182 33-42.

Panula P, Aarnisalo AA \& Wasowicz K 1996 Neuropeptide FF, a mammalian neuropeptide with multiple functions. Progress in Neurobiology 48 461-487.

Panula P, Kalso E, Nieminen M, Kontinen VK, Brandt A \& Pertovaara A 1999 Neuropeptide FF and modulation of pain. Brain Research 848 191-196.

Parker DB, Coe IR, Dixon GH \& Sherwood NM 1993 Two salmon neuropeptides encoded by one brain cDNA are structurally related to members of the glucagon superfamily. European Journal of Biochemistry 215 439-448.

Parker DB, Power ME, Swanson P, Rivier J \& Sherwood NM 1997 Exon skipping in the gene encoding pituitary adenylate cyclase-activating polypeptide in salmon alters the expression of two hormones that stimulate growth hormone release. Endocrinology 138 414-423.

Satake H, Hisada M, Kawada T, Minakata H, Ukena K \& Tsutsui K 2001 Characterization of a cDNA encoding a novel avian hypothalamic neuropeptide exerting an inhibitory effect on gonadotrophin release. Biochemical Journal 354 379-385.

Sawada K, Ukena K, Kikuyama S \& Tsutsui K 2002a Identification of a cDNA encoding a novel amphibian growth hormone-releasing peptide and localisation of its transcript. Journal of Endocrinology 174 395-402.

Sawada K, Ukena K, Satake H, Iwakoshi E, Minakata H \& Tsutsui K $2002 b$ Novel fish hypothalamic neuropeptide: cloning of a cDNA encoding the precursor polypeptide and identification and localisation of the mature peptide. European Journal of Biochemistry $2696000-6008$.

Swanson P 1995 Radioimmunoassay of fish growth hormone, prolactin, and somatolactin. In Biochemistry and Molecular Biology of Fishes, vol 3, pp 545-565. Eds PW Hochaka \& TP Mommsen. New York, NY: Elsevier.

Tsutsui K, Saigoh E, Ukena K, Teranishi H, Fujisawa Y, Kikuchi M, Ishii S \& Sharp PJ 2000 A novel avian hypothalamic peptide inhibiting gonadotrophin release. Biochemical and Biophysical Research Communications 275 661-667.

Ubuka T, Ueno M, Ukena K \& Tsutsui K 2003 Developmental changes in gonadotrophin-inhibitory hormone in the Japanese quail (Coturnix japonica) hypothalamo-hypophysial system. Journal of Endocrinology 178 311-318.

Ukena K, Ubuka T \& Tsutsui K 2003a Distribution of a novel avian gonadotrophin-inhibitory hormone in the quail brain. Cell and Tissue Research 312 73-79.

Ukena K, Koda A, Yamamoto K, Kobayashi T, Iwakoshi-Ukena E, Minakata H, Kikuyama S \& Tsutsui K 2003 b Novel neuropeptides related to frog growth hormone-releasing peptide: isolation, sequence, and functional analysis. Endocrinology 144 3879-3884.

Ukena K \& Tsutsui K 2005 A new member of the hypothalamic RF-amide peptide family, LPXRF-amide peptides: structure, localisation, and function. Mass Spectrometry Reviews 24 469-486.

Received 17 November 2005

Accepted 5 December 2005 